\title{
Study of Powdery Mildew Resistance in seven Lines of Snow Pea, Pisumsativum
}

\author{
Anchan Chompupoung \\ Royal Project Foundation, Suthep, Muang, Chiang Mai, 50200, Thailand
}

$\&$

Center of Excellence on Agricultural Biotechnology

(AG-BIO/PERDO-CHE), Bangkok 10900, Thailand

\&

Department of Plant Science and Natural Resources, Faculty of Agriculture

Chiang Mai University, Chiang Mai, 50200, Thailand

E-mail: Anchan359@gmail.com

Siripong Kumphai

Department of Agriculture, Jatujak, Bangkok, 10900, Thailand

Chatree Sittigul \& Angsana Akkarapisan

Department of Entomology and Plant Pathology

Faculty of Agriculture, Chiang Mai University

Chiang Mai 50200, Thailand

Weenun Bundithya \& Nuttha Potapohn

Department of Plant Science and Natural Resources

Faculty of Agriculture, Chiang Mai University

Chiang Mai 50200, Thailand

Received: November 9, 2011

Accepted: December 2, $2011 \quad$ Online Published: April 1, 2012

doi:10.5539/jas.v4n5p209

URL: http://dx.doi.org/10.5539/jas.v4n5p209

This research is financially supported by Royal Project Foundation, and partially supported by the Center of Excellence on Agricultural Biotechnology, Science and Technology Postgraduate Education and Research Development Office, Office of Higher Education Commission, Ministry of Education (AG-BIO/PERDO-CHE).

\footnotetext{
Abstract

Snow pea is one of the important crops grown on highland of Thailand. However, it is very susceptible to powdery mildew. Thus, resistant cultivar increases the production of this crop at a reduced costs. Seven pea lines/cultivars, namely P117, P185, P309, No.3, No.4, No.5 and Fang No.7, were evaluated for phenotypic powdery mildew resistance at Pang Da Royal Agricultural Station, Samoeng district, Chiang Mai during the period of November, 2007 - March, 2008. They were divided into 3 groups: highly resistant group (R) i.e. P117, P185 and P309, moderately resistant group (M) i.e. No.3, No.4 and 5, and susceptible group (S) i.e. Fang No.7. In addition, DNA marker for powdery mildew resistance, er, was tested using PCR technique with 3 primers, ScOPD10, OPU17 and OPO02. It was found that only ScOPD10 could yield an 850-bp marker specific to resistant group. DNA sequencing of this 850 bp marker showed 618-624 bases. The sequence was compared
} 
with databases in NCBI GenBank. After BLAST searches, the 618-624 base sequences had 90-91\% homology to the DNA sequence from clone JICPSV-598E15, complete sequence of $P$. sativum.

Keywords: Pea, Powdery mildew resistance, PCR Technique

\section{Introduction}

Snow pea, Pisumsativum L.(Fabaceae), is an important source of protein which has continuously increased market demand and becomes popular for the Thai consumers. Fresh frozen pea pod has been exported to Japan as much as fresh consumption in Thailand. Because snow pea is a major winter annual pulse crop which needs cool condition for their growth and yield, the major production area is located on the highland especially in the northern part of Thailand such as Chiang Mai, Chiang Rai and on the highland of Petchaboon and Tak Provinces (Pongphal et al., 2003). In Thailand, powdery mildew is a common disease of snow pea, and the cause of this disease is Oidium spp. (Wanasiri, 2007). It is prevalent in many areas of Thailand where pea is cultivated in every season (Khumpai et al., 2001). The commercial snow pea cultivars, widely used by farmers, produce high yield but are very susceptible to powdery mildew disease. The disease infection can rapidly spread when the growing climates are favorable to the disease. Severe damage about $25-50 \%$ to the production could occur (Warkentin et al., 1998). Moreover, the number of pods per plant, seeds per pod, heights and the number of nodes could drastically decrease (Fondevilla et al., 2007). Therefore, chemical control of the disease is needed, but it increases cost of production. Moreover, it is not safe to the producers, consumers and environment. Thus, the use of resistant varieties to powdery mildew is more efficient, economical and ecologically sound for controlling disease (Keller et al., 2000). There is a report that the resistance to the powdery mildew disease in pea is controlled by recessive gene $e r-1$ and (or) er-2. (Tiwari et al.,1998). In addition, the resistant er-3 gene has been found in P. fulvum which originated in eastern Mediterranean and Near East areas. The presence of resistant gene showed the dominant specific character and also depended on the climate (Fondevilla et al., 2007). Marker-assisted selection (MAS) may be used to shorten time needed to fix resistance to powdery mildew in segregating populations. Markers tightly linked to gene of interest increase the efficiency and accuracy of selection (Sanchez et al., 2000). DNA maker is a tool that has been widely used to identify and separate resistant pea cultivar from the susceptible cultivar by using polymorphic band of er gene linkage such as ScOPO1 $8_{1200}$ and ScOPE16 $6_{1600}$ in Canadian resistant cultivar (Tiwari et al.,1998), OPU17 1000 and ScOPD10 $0_{650}$ in Indian resistant cultivar whereas OPO02 ${ }_{1400}$ in Indian susceptible cultivars (Janila and Sharma, 2004). Moreover, the presence of DNA marker, er gene, has specific linkage to landrace cultivar. The objective of this study was to identify the er gene-linked molecular marker in snow peas which were developed in Thailand by using three primers, OPU17, OPO02 and ScOPD10 which were reported by Janila and Sharma (2004).

\section{Materials and Methods}

\subsection{Phenotypic Evaluation of Powdery Mildew Resistance}

This research was conducted in the winter season from November 2006 to March 2007 at Pang Da Royal Agricultural Station, Samoeng District, Chiang Mai. Seven pea lines/cultivars, P117, P185, P309, No.3, No.4, No.5 and Fang No.7, were used. Randomized Complete Block Design with 6 replications was used. Fourteen-day prior to transplanting, Fang No.7, the susceptible cultivar, was planted as source of Oidium sp. inoculum. Evaluation was done according to the presence of disease on the $4^{\text {th }}, 7^{\text {th }}, 10^{\text {th }}$ nodes and a whole plant at 45, 55, 65 and 75 days, respectively. Disease severity scoring was based on the amount of disease on each leaf and calculated for the percentage of infected area ranging from 0 to 100\% (Ondrej et al., 2005; Young et al., 1993) and the scores were analyzed by Statistix version 8.0.

\subsection{DNA Marker Linked to Powdery Mildew Resistance in Snow Pea}

Genomic DNA of 7 pea lines/cultivars was extracted from young leaf using Plant DNAZOL Reagent (Invitrogen Co., Ltd.). The $20 \mu \mathrm{l}$ reaction mixture was composed of $15 \mathrm{ng}$ DNA template, $1 \mathrm{x}$ PCR buffer (10mM Tris-HCl $\mathrm{pH} 8.3,50 \mathrm{mM} \mathrm{KCl}, 0.2 \mathrm{mM} \mathrm{MgCl}$, Enhancer solution), $0.5 \mathrm{mM}$ dNTPs, 80 ng primer, 1 unit i-Taq ${ }^{\mathrm{tm}} \mathrm{DNA}$ polymerase (iNtRON biotechnology, Inc.) and distilled water. Three primers, one SCAR primer, ScOPD10 and two RAPD primers, OPU17 and OPO02, obtained from Operon Technologies Inc., Alameda, California, USA), were used for PCR reaction. The amplification was done following the method of Janila and Shama (2004), 1 cycle of $92^{\circ} \mathrm{C}$ for $120 \mathrm{sec}$. then $92^{\circ} \mathrm{C}$ for $30 \mathrm{sec}, 42^{\circ} \mathrm{C} 30 \mathrm{sec}$, and $72^{\circ} \mathrm{C} 60 \mathrm{sec}$. for 44 cycles and $72^{\circ} \mathrm{C} 300 \mathrm{sec}$. for 1 cycle. PCR product was kept overnight at $4^{\circ} \mathrm{C}$ before checking the quality and quantity by $1.7 \%$ agarose gel electrophoresis. The amplified DNA bands were stained in $0.1 \mu \mathrm{l} / \mathrm{ml}$ ethidium bromide and photographed under UV light using BIODOC-It ${ }^{\mathrm{TM}}$ M-20 System (Gibthai Co., Ltd.). 


\subsection{DNA Sequence Analysis}

The 850-bp PCR products derived from two plants each of three resistant lines, P117, P185 and P309, were purified and sequenced at Pacific Science Co., Ltd.

\section{Results}

\subsection{Phenotypic Evaluation of Powdery Mildew Resistance}

The percentage of powdery mildew infection on the leaf surface areas of 7 pea lines/cultivars was measured. The results showed that in all stages of growth of cultivar Fang No.7, the highest severity on infection $(100 \%)$ was observed on the leaves. Base on the disease severity ratings of the study, the tested materials were classified into 3 groups as follows; highly resistant (R), lines P117, P185 and P309; moderately resistant (M), lines No.3, No.4 and No.5 and susceptible (S), cultivar Fang No.7. At 45 days after transplanting, evaluation was carried out on the $4^{\text {th }}$ node stage of growth, and it was found that the resistant group showed only $0.3-1.9 \%$ of leaf area infection, whereas the moderately resistant and susceptible groups showed $62.1-85.1$ and $100 \%$ of leaf infections, respectively (Figure 1). At 55 days after transplanting, evaluation was done again on the $7^{\text {th }}$ node, and it was noted that there was no infection on resistant groups, whereas the moderately resistant and susceptible groups showed $18.9-47.7$ and $73.9 \%$ of infections, respectively. Then at $11^{\text {th }}$ node or at 65 days after transplanting, disease rating was recorded and it was observed that only light infection of 1.6-2.3\% was seen of leaves of the resistant lines. Meanwhile the moderately resistant and susceptible groups showed 37.8-60.4 and 90.0\% of infections, respectively. Finally, powdery mildew disease scoring of the whole plant was carried out at 75 days after transplanting, and it was found that the resistant group showed only $4.5-10.9 \%$ disease infections. The moderately resistant and susceptible groups showed 32.4-56.6 and 96.0\% disease infections, respectively.

\subsection{DNA Marker Linked to Powdery Mildew Resistance in Snow Pea}

Three primers, ScOPD10, OPU17 and OPO02 were used to amplify DNA in PCR reaction. It was found that all 3 primers generated the multiple sizes of DNA bands of each sample. However, primer SCOPD10 produced a total of 13 DNA bands and this primer could yield polymorphic DNA band at $850 \mathrm{bp}$. only in the resistant lines, P117 P185 and P309 (Figure 2A), while the powdery mildew susceptible lines/cultivars, lines No.3, No.4, No.5 and cultivar Fang No.7, showed no band of this size. The primer OPU17 and OPO02 produced a total of 6 and 8 DNA bands, respectively (Figure 2B-C). These two primers could not produce polymorphic band in either resistant or susceptible cultivars as reported in Indian cultivars according to Janila and Sharma (2004).

\subsection{DNA Sequence Analysis}

ScOPD10 primer was used to detect resistant DNA marker in 3 resistant pea lines, P117, P185 and P309. The 850-bp PCR products of 3 resistant lines were sequenced by Pacific Science CO., Ltd. The result showed that the DNA sequences for each line were 618,621 and 624, respectively, and they were compared with DNA sequence databases at National Center for Biotechnology Information (NCBI) GenBank. After BLAST searches of sequence, DNA sequence showed 91, 90 and 91\% homology to the DNA sequence from clone JICPSV-598E15, complete sequence of $P$. sativum. (Table 1, Figure 3-5).

\section{Discussions}

\subsection{Phenotypic Evaluation of Powdery Mildew Resistance}

Based on the result of this study, 7 lines/cultivars of snow pea were identified for the resistant levels to powdery mildew disease in the field conditions. The disease evaluation showed that it started on all tested materials at flowering stage. The greater amount of spore and mycelium fully covered the leaves of three lines, No.3, No.4, No.5 and cultivar Fang No.7. However, it was found that at every growth stages of cultivar Fang No.7, the commercial cultivar which is widely used in Thailand, was infected by the disease at the highest percentage level. The differential resistant level in each cultivar was influenced by many factors such as pathogen races, environmental conditions for pathogen and plant (Vaid and Tyagi, 1997). According to the statistical analysis of the observed disease percentages tested, snow pea lines/cultivar in the study could be divided into 3 groups as follows; highly resistant cultivar group (R) i.e. lines P117, P185 and P309, moderately cultivar group (M) i.e. lines No.3, No.4 and No.5 and susceptible group (S) i.e. cultivar Fang No.7. Based on to the result of phenotypic assessment, it could be stated that only three lines of P117, P185 and P309 were resistant to powdery mildew, due to the lowest percentages of disease infection on the leaves and the whole plants. Since the 7 snow pea lines/cultivars in the experiment were tested under the same conditions, the occurrence of the resistance must have been the result of the resistant gene. Tiwari et al.(1998) stated that the resistance to the powdery mildew disease in pea ( $P$. sativum) is controlled by recessive gene er-1 and (or) er-2 and the resistance gene er- 1 may be 
present in many resistant lines from around the world. However, the powdery mildew resistance which was found in this study might not have been the same genes as previously reported.

\subsection{DNA Marker Linked to Powdery Mildew Resistance in Snow Pea}

In this study, the resistant DNA marker in 7 lines/cultivars of snow pea was identified using three primers, ScOPD10, OPU17 and OPO02. None of them could yield band that had the same size as reported by Janila and Sharma (2004). That might be due to the difference of the origin of germplasm. Although, the SCAR marker, ScOPD10, was developed to be used in identifying powdery mildew disease resistance in Canadian germplasm by Timmerman et al. (1994) and Tiwari et al. (1998) whereas this germplasm has been less employed in Indian pea breeding programme. Only $80 \%$ of the result was reliable when this primer was used with Indian cultivars. Meanwhile, one of the two markers developed by Tiwari et al. (1998) could not differentiate resistant and susceptible lines of the Indian origin (Janila and Sharma, 2004). Since the origin of snow pea lines/cultivar used in this study is not known and they might have contained different genetic origin from those of Canadian and Indian origins. Thus, when primer, ScOPD10, was used, it could not yield band that has the same size of $650 \mathrm{bp}$ as reported in Canadian cultivars (Timmerman et al., 1994) and Indian cultivars (Janila and Sharma, 2004). However, band at $850 \mathrm{bp}$ was found in all the resistant lines, lines P117, P185 and P309. The difference in size may occur according to the difference of pea genetic background (Fondevilla et al., 2008). On the other hand, other two primers, OPU17 and OPO02, failed to detect any marker. That might occur due to the markers of OPU17 and OPO02, were RAPD primers, which were not specific and there were many limitations of this method, especially, high sensitivity to reaction conditions that reduces reproducibility of the results obtained in different laboratories (Ek et al., 2005). However, the specific DNA band at $850 \mathrm{bp}$. could be used to confirm the powdery mildew resistance in snow pea cultivar in Thailand.

\subsection{DNA Sequence Analysis}

The 850-bp PCR products of 3 resistant lines, P117, P185 and P309, were sequenced and the result showed 618624 of the base number. After comparing with DNA sequence databases at National Center for Biotechnology Information (NCBI) GenBank. DNA sequence showed 90-91\% homology to the DNA sequence from clone JICPSV-598E15, complete sequence of P. sativum. In addition, this DNA sequence was also similar to DNA sequence of BARE-1 gene in barley and RIRE-1 gene in rice (Smykal, 2009). BARE-1 gene in barley was resistant gene to powdery mildew caused by E. graminis f. sp. Hordei (Wei,1999). Thus, it might be stated that resistant pea lines in this study contained the same resistant gene as other powdery mildew resistant pea lines.

\section{References}

Ek, M., Eklund M., Von Post R., Dayteg C., Henriksson T., Weibull P., Ceplitis A., Isaac P. \& Tuvesson S. (2005). Microsatellite marker for powdery mildew resistance in pea (Pisum sativum). Hereditas, 142, 86-91, http://dx.doi.org/10.1111/j.1601-5223.2005.01906.x

Fondevilla S., Torres A. M., Moreno M. T. \& Rubiales D. (2007). Identification of a New Gene for Resistance to Powdery Mildew in Pisum fulvum, a Wild Relative of Pea. Breeding Science, 57, 181-184, http://dx.doi.org/10.1270/jsbbs.57.181

Fondevilla, S., Rubiales D. \& Moreno M. T. (2008). Identification and validation of RAPD and SCAR markers linked to the gene Er3 conferring resistance to Erysiphe pisi DC in pea. Mol. Breeding, 22, $193-200$. http://dx.doi.org/10.1007/s11032-008-9166-6

Janila, P. \& Sharma B. (2004). RAPD and SCAR Markers for Powdery Mildew Resistance Gene er in Pea. Plant Breeding, 123, 271-274. http://dx.doi.org/10.1111/j.1439-0523.2004.00963.x

Keller, B., Feuillet C. \& Messmer M. (2000). Genetics of disease resistance. In A.J. Slusarenko, R.S.S. Fraser, and L.C. van Loon (Eds.). Mechanisms of Resistance to Plant Diseases. Kluwer Academic Publishers, Dordrecht, Netherland. pp. 101-160. http://dx.doi.org/10.1007/978-94-011-3937-3_5

Khumpai, S., Wicescang A., Saranar J. \& Somlit P. (2001). Varietal improvement of snow pea for powdery mildew resistance. Plant diseases Research Department of Agriculture. [Online] Available: www.doa.go.th/webice/library/library/plant_project46/502.pdf

Pongphal D., Seephueng C., Ratanang P., Reungpradit P., Muengmoon P., Wongnunta N. \& Sankham P. (2003). Investigations of Sweet Pea Fresh Pod and Commercial Seed Production. Royal Project Foundation Report, 2003. Project no. 20102. Royal Project Foundation: 36 p. 
Ondrej, M., R. Dostalova, \& L. Odstrcilova. (2005). Response of Pisum sativum Germplasm Resistant to Erysiphe pisi to Inoculation with Erysiphe baeumleri, a New Pathogen of Pea. Plant Protect. Sci., 41, 95-103. http://www.journals.uzpi.cz/publicFiles/16843.pdf

Sanchez, A. C., Brar S. D., Haung N., Li Z. \& Khush G. S. (2000). Sequence tagged site marker-assisted selection for three bacterial blight resistance genes in rice. Crop Sci., 40, $792-797$. http://dx.doi.org/10.2135/cropsci2000.403792x

Smykal, P., Kalendar R., Ford R., Macas J. \& Griga M. (2009). Evolutionary conserved lineage of Angela family retrotransposons as a genome-wide microsatellite repeat dispersal agent. Heredity, 103, $157-167$. http://dx.doi.org/10.1038/hdy.2009.45

Timmerman, G.M., Frew T.J., Weeden N.F., Miller A.L. \& Golden D.S. (1994). Linkage Analysis of er-1, a Recessive Pisum sativum Gene for Resistance to Powdery Mildew Fungus (Erysiphe pisi D.C.). Theor. Appl. Genet., 88, 1050-1055. http://dx.doi.org/10.1007/BF00220815

Tiwari, K.R., Penner G.A. \& Warkentin T.D. (1998). Identification of Coupling and Repulsion Phase RAPD Markers for Powdery Mildew Resistance Gene er-1 in Pea. Genome, 41, $440-444$. http://onlinelibrary.wiley.com/doi/10.1111/j.1439-0523.2004.00963.x/abstract

Vaid, A. \& Tyagi P. D. (1997). Genetics of powdery mildew resistance in pea. Euphytica, 96, $203-206$. http://dx.doi.org/10.1023/A:1002953129003

Wanasiri, N. (2007). Identification and Classification of Some Powdery Mildew Anamorpha Using Light and Scanning Electron Microscopes. Master of Science Thesis, Department of Agriculture. Chiang Mai University. $131 \mathrm{p}$.

Warkentin, T.D., Rashid K.Y. \& Xue A.G. (1998). Fungicidal control of powdery mildew in field pea. Can. J. Plant Sci., 76, 933-935. http://dx.doi.org/10.4141/cjps96-156

Wei, F., Gobelman W. K., Morroll S.M., Kurth J., Mao L., Wing R., Leister D., Schulze L. P. \& Wise R.P. (1999). The Mila (Powdery mildew) resistance cluster is associated with three NBS-LRR gene families and suppressed recombination within a $240-\mathrm{kb}$ DNA interval on chromosome 5s (1HS) of barley. Genetics, 153, 1929-1948, http:/www.genetics.org/content/153/4/1929.short

Young, N., Danesh D., Menancio-Hautea D. \& Kumar L. (1993). Mapping oligogenic resistance to powdery mildew in mungbean with RFLPs. Theor. Appl. Genet., 87, 243-249. http://dx.doi.org/10.1007/BF00223772

Table 1. Description of three specific bands comparing with NCBI database

\begin{tabular}{|c|c|c|c|c|c|}
\hline Lines & Bases & Accession & \multicolumn{1}{c|}{ Description } & $\begin{array}{c}\text { Query } \\
\text { Coverage }\end{array}$ \\
\hline P117 & 618 & CU655881.10 & $\begin{array}{l}\text { P. sativum DNA sequence from clone JICPSV-598E15, } \\
\text { complete sequence }\end{array}$ & $91 \%$ \\
\hline P185 & 621 & CU655881.10 & $\begin{array}{l}\text { P. sativum DNA sequence from clone JICPSV-598E15, } \\
\text { complete sequence }\end{array}$ & $90 \%$ \\
\hline P309 & 624 & CU655881.10 & $\begin{array}{l}\text { P. sativum DNA sequence from clone JICPSV-598E15, } \\
\text { complete sequence }\end{array}$ & $91 \%$ \\
\hline
\end{tabular}



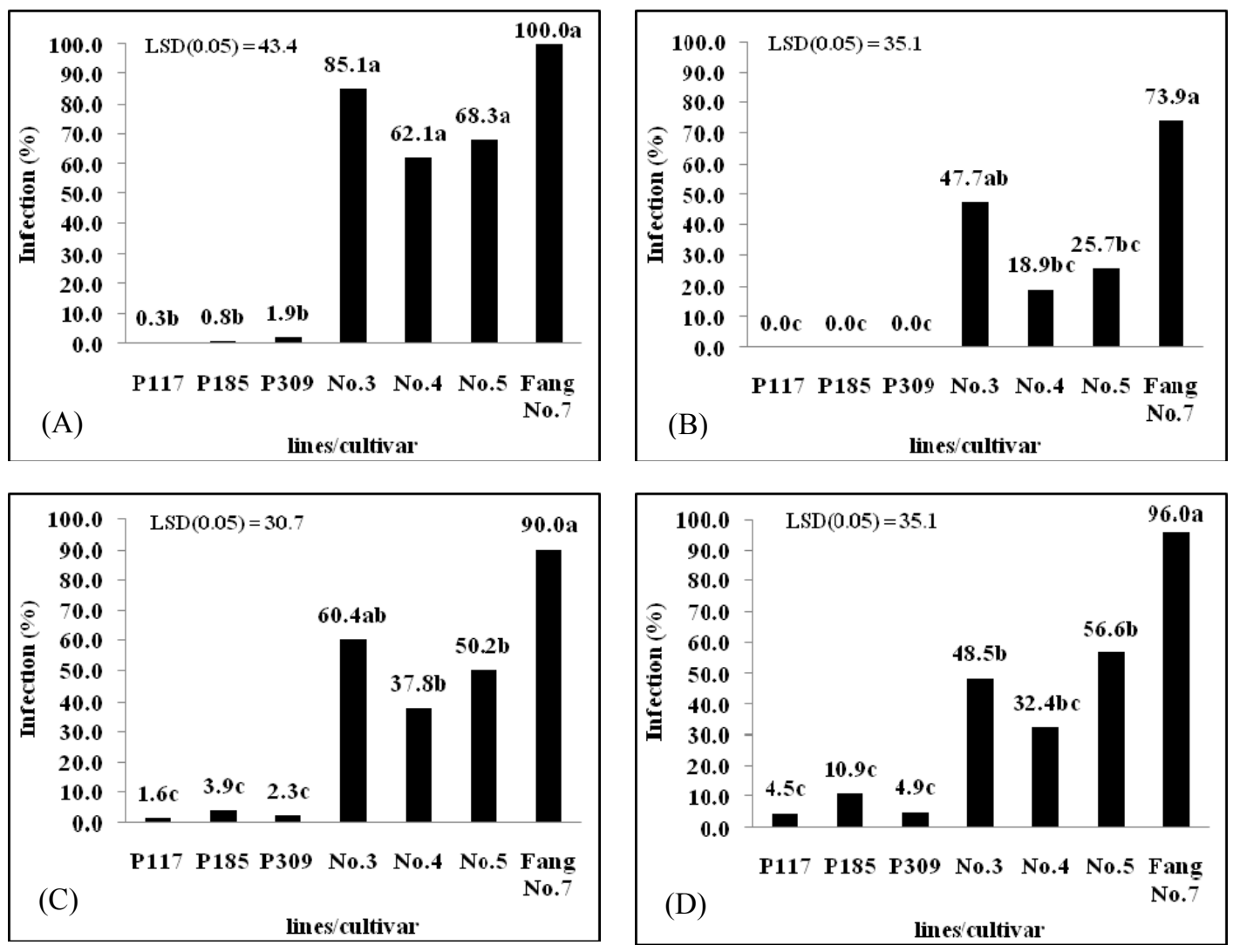

Figure 1. Percentage of powdery mildew infection on leaf surface area at the $4^{\text {th }}$ node $(A), 7^{\text {th }}$ node (B), $11^{\text {th }}$ node $(\mathrm{C})$ and whole plant (D) in 7 pea lines/cultivars 

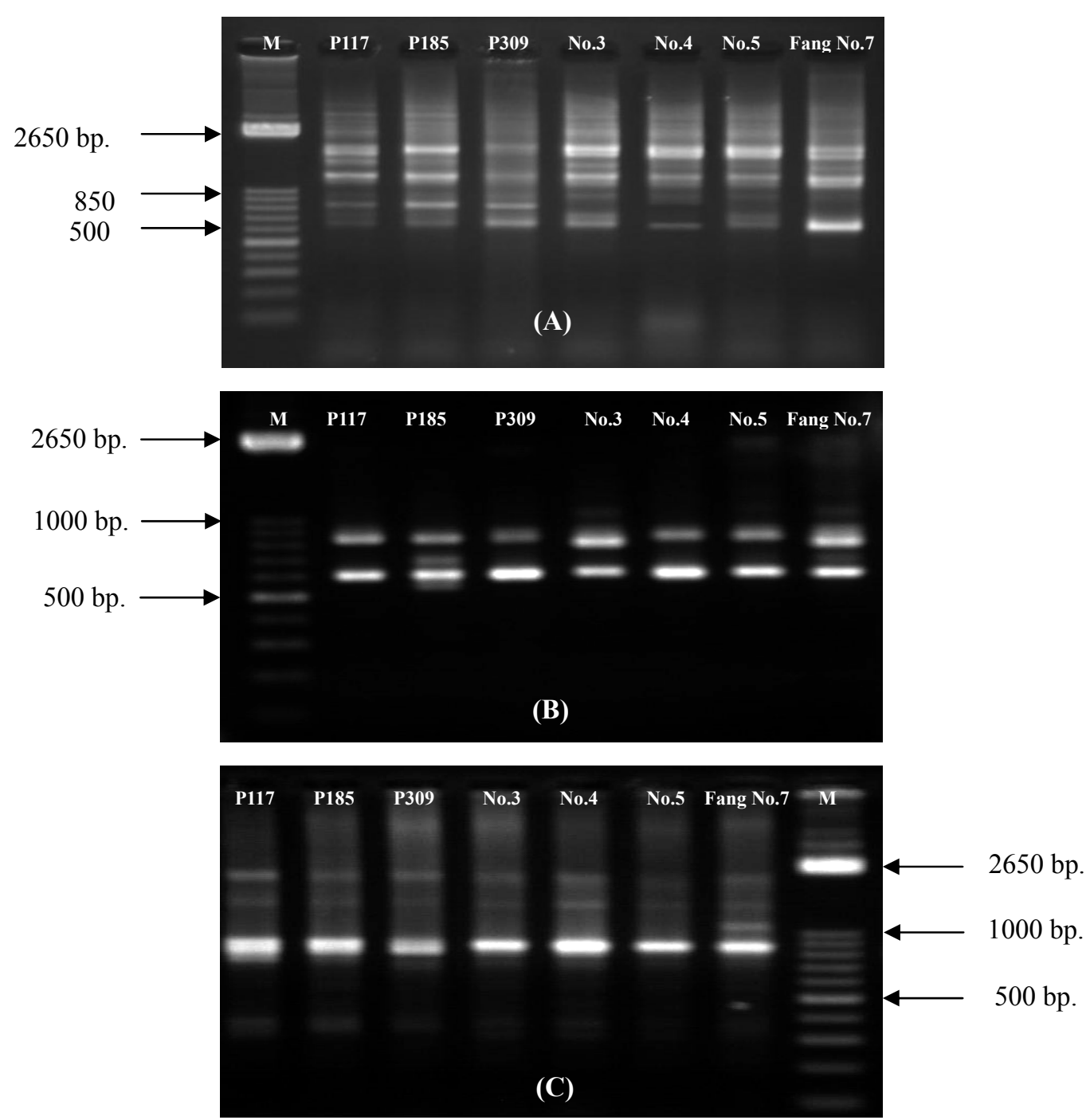

Figure 2. DNA fingerprinting generated by primer ScOPD10 (A), primer OPU17 (B) and primer OPO02 (C) of 7 pea lines/cultivars which were divided into 3 groups: 1) resistance (R), P117, P185 and P309; 2) moderate resistance (MR), No.3, No.4 and No.5 and 3) susceptible (S), Fang No.7. The 850-bp DNA marker could be yielded only in R group 
TAAAAATTGAAATACTCAACAGCTCAATATGCATGAATGATGAATTAAAGAACTTCCCTTGATTGT ATTTGAGCAAAGGTTGAGGTTTCTTCATGAGCAAGGCACAATTGATACATAGATGAATTAGGGTTT CCTTGGGAAACAAGCCTCAAACCCTTTGGTTTGGTTTGATCAAAACGATGAATTGAGATACTTGGG AGGCATATTTGATGGATTAGAGATTTGGGAACCATTGCCATGCTTTCTTTCATCTTCTCTTGGCTAT ATCAATGCACATAGGATCTCCTAGAAGCTTTGGACCTTATGACTGTTCAAGCTACAAACAAAAGAT GTTAGTGACATATTTTTATGCTTTTGGTTAGTGAATAAAAAATGAGAAAAGAAATAATATACAATT TAAGCATGCTTTGTGATCTCAAACCAACTCTCAAAAGATCCCACCCTAGGGTAAGAGCCAAGATGC TTATGATCCTTAAGGCAAGATGCAAATGCAATGTTATGATGCCATGAGGGATCTTAGGGTCAAATA GGGGTCTTACAGTATGTTCGAGCATGCGATATGTTCGGGTATATTTTCGCTAGCTTCACGGACATAG TACGGACACTGTTTAGGTGTAGACCATAT

Figure 3. DNA sequence of the specific band of line P117

CTTACAATTATTCGAATCGAGAGCTCCAACTTCTGCAATTCTAGGCTCTGGGTTTGGGTTGGGGGTG CTCCTGTCGTGCAACGGATATACATGAGCAAGGCACAATTGATACATAGATGAATTAAGGTTTCCC TGGGAAACAAGCCTCAAACCCTTTGGTTTGGTTTGATCAAAACGATGAATTGAGATACTTGGGAGG CATATTTGATGGATTAGAGATTTGGGAACCATTGCCATGCTTTCTTTCATCTTCTCTTGGCTATATCA ATGCACATAGGATCTCCTAGAAGCTTTGGACCTTATGACTGTTCAAGCTACAAACAAAAGATGTTA GTGACATATTTTTATGCTTTTGGTTAGTGAATAAAAAATGAGAAAAGAAATAATATACAATTTAAG CATGCTTTGTGATCTCAAACCAACTCTCAAAAGATCCCACCCTAGGGTAAGAGCCAAGATGCTTAT GATCCTTAAGGCAAGATGCAAATGCAATGTTATGATGCCATGAGGGATCTTAGGGTCAAATAGGG GTCTTACAGTATGTTCGAGCATGCGATATGTTCGGGTATATTTTCGCTAGCTTCACGGACATAGTAC GGACACTGTTTAGGTGTAGACCA

Figure 4. DNA sequence of the specific band of line P185

CGTAAAACACGAGTCTCAACAGTTCAATATGCATGAAATGATGAATTAAAGAACTTCCCTTGATTG TATTTGAGCAAAGGTTGAGGTTTCTTCATGAGCAAGGCACAATTGATACATAGATGAATTAGGGTT TCCTTGGGAAACAAGCCTCAAACCCTTTGGTTTGGTTTGATCAAAACGATGAATTGAGATACTTGG GAGGCATATTTGATGGATTAGAGATTTGGGAACCATTGCCATGCTTTCTTTCATCTTCTCTTGGCTA TATCAATGCACATAGGATCTCCTAGAAGCTTTGGACCTTATGACTGTTCAAGCTACAAACAAAAGA TGTTAGTGACATATTTTTATGCTTTTGGTTAGTGAATAAAAAATGAGAAAAGAAATAATATACAAT TTAAGCATGCTTTGTGATCTCAAACCAACTCTCAAAAGATCCCACCCTAGGGTAAGAGCCAAGATG CTTATGATCCTTAAGGCAAGATGCAAATGCAATGTTATGATGCCATGAGGGATCTTAGGGTCAAAT AGGGGTCTTACAGTATGTTCGAGCATGCGATATGTTCGGGTATATTTTCGCTAGCTTCACGGACATA GTACGGACACTGTTTAGGTGTAGACCA

Figure 5. DNA sequence of the specific band of line P309 